BIOS : Jurnal Teknologi Informasi dan Rekayasa Komputer

Vol. 2, No. 2, September 2021, hlm. 73 - 80

ISSN: 2722-0850

Laman Jurnal: http://bios.sinergis.org

\title{
SISTEM PENDUKUNG KEPUTUSAN PEMILIHAN VITAMIN-C DI MASA PANDEMI COVID-19 MENGGUNAKAN METODE WEIGHTED PRODUCT (WP)
}

\author{
Wardah Ramadhanty ${ }^{1}$, Siti Ernawati ${ }^{2}$ \\ ${ }^{1}$ Sistem Informasi, Universitas Nusa Mandiri,wardahramadhanty28@email.com \\ ${ }^{2}$ Sistem Informasi, Universitas Nusa Mandiri, siti.ste@nusamandiri.ac.id
}

\begin{tabular}{|c|c|}
\hline Keywords: & ABSTRACT \\
\hline $\begin{array}{l}\text { Weighted Product }(\text { WP }) \\
\text { Method, } \\
\text { Vitamin-C, } \\
\text { DSS }\end{array}$ & $\begin{array}{l}\text { Vitamin-C is a kind of water-soluble vitamins and can improve the body's } \\
\text { resistance to disease. Vitamin-C can be found in various types of food such } \\
\text { as vegetables and fruit. However, the body requires additional intake of } \\
\text { vitamin-c aside from the food, that is a vitamin supplement as a complement } \\
\text { to the nutritional needs of the body. In the pandemic Covid-19 is often } \\
\text { associated with nutrition in the form of Vitamin-C to enhance the body's } \\
\text { immune also to help protect body cells against free radicals, including some } \\
\text { kind of virus. The number of forms and brands of Vitamin-C makes the } \\
\text { community are often confused choosing a product Vitamin-C where to be } \\
\text { consumed. To provide convenience to the public in choosing the product } \\
\text { Vitamin-C, there is a solution to overcome these problems is the existence of } \\
\text { a decision-making system for selecting products Vitamin-C using the } \\
\text { Method of Weighted Products (WP). The method of Weighted Product } \\
\text { method is a method of the determination in a decision by way of } \\
\text { multiplication to be able to connect the value of the attribute. The results of } \\
\text { the calculations in the study is ranking the highest value that can be } \\
\text { recommended as the primary choice for people to choose products vitamin-c } \\
\text { to be consumed in the pandemic covid-19. From the results of the } \\
\text { calculation can be specified Brand of Vitamin-C You C } 1000 \text { to get the value } \\
\text { of the highest 0,0253. Because You C } 1000 \text { vitamin supplements in liquid } \\
\text { form that is easily taken, there are also Vitamin-C } 1000 \text { milligrams that can } \\
\text { be consumed every day. }\end{array}$ \\
\hline
\end{tabular}

\section{Kata Kunci}

\section{Metode Weighted Product}

(WP),

Vitamin-C,

SPK

\begin{abstract}
ABSTRAK
Vitamin-C merupakan jenis vitamin yang larut dalam air dan dapat meningkatkan daya tahan tubuh terhadap penyakit. Vitamin-C dapat ditemukan dalam berbagai jenis makanan seperti sayuran dan buah. Namun tubuh membutuhkan asupan tambahan vitamin-c selain dari makanan, yaitu suplemen vitamin sebagai pelengkap kebutuhan nutrisi tubuh. Di masa pandemi Covid-19 sering dihubungkan dengan pemberian nutrisi berupa Vitamin-C untuk meningkatkan imun tubuh juga untuk membantu melindungi sel-sel tubuh melawan radikal bebas termasuk beberapa jenis virus. Banyaknya bentuk dan merk Vitamin-C membuat masyarakat sering bingung memilih produk Vitamin-C mana untuk dikonsumsi. Untuk memberikan kemudahan kepada masyarakat dalam memilih produk Vitamin$\mathrm{C}$, terdapat solusi untuk mengatasi masalah tersebut yaitu adanya suatu sistem pengambilan keputusan untuk memilih produk Vitamin-C menggunakan Metode Weighted Products (WP). Metode Weighted Product merupakan metode penentuan dalam sebuah keputusan dengan cara perkalian untuk dapat menghubungkan nilai atribut. Hasil dari perhitungan pada penelitian merupakan perangkingan nilai tertinggi yang dapat direkomendasikan sebagai pilihan utama bagi masyarakat dalam memilih produk vitamin-c untuk dikonsumsi di masa pandemi covid-19. Dari hasil perhitungan dapat ditentukan Merk Vitamin-C You C 1000 mendapatkan nilai tertinggi yaitu 0,0253. Karena You C 1000 suplemen vitamin berbentuk
\end{abstract}


cair yang mudah diminum, juga terdapat kandungan Vitamin-C 1000 miligram yang dapat dikonsumsi setiap hari.

\section{Korespondensi Penulis:}

Nama penulis : Wardah Ramadhanty, Siti Ernawati

Afiliasi : Universitas Nusa Mandiri

Alamat: Jl. Raya Jatiwaringin No.2, RT.2/RW.13, Cipinang Melayu, Jakarta Timur

Telepon : +6281932196259

Email: wardahramadhanty28@email.com, $\underline{\text { siti.ste@ nusamandiri.ac.id }}$

\section{PENDAHULUAN}

Tahun 2020 merupakan tahun krisis kesehatan yang dihadapi seluruh negara di dunia, sejak merebaknya Corona Virus (Covid-19) yang bermula dari Wuhan,China. Penyakit Covid-19 telah mendapat perhatian seluruh negara di dunia. Kesehatan Dunia Organisasi (WHO) secara resmi menyatakan pandemi Covid-19 sebagai darurat kesehatan masyarakat yang menjadi perhatian internasional. Virus Covid-19 adalah kumpulan virus yang bisa menginfeksi sistem pernapasan manusia dan banyak dampak negatif yang disebabkan oleh Virus Covid-19, diantaranya adalah infeksi pernapasan ringan maupun berat, seperti pneumonia (infeksi paru-paru), middle east respiratory syndrome (MERS), dan severe acute respiratory syndrome (SARS). Gejala awal untuk mengetahui bahwa seseorang mengalami infeksi Virus Covid-19 adalah flu, sesak napas, nyeri di bagian dada, batuk berdahak ataupun berdarah, demam, sakit kepala. Gejala-gejala tersebut muncul ketika tubuh bereaksi melawan Virus Covid-19 [1].

Pada masa pandemi Covid-19 sering dihubungkan dengan pemberian nutrisi berupa Vitamin-C untuk meningkatkan imun tubuh. Manfaat Vitamin-C membantu melawan radikal bebas beberapa jenis virus dan melindungi sel-sel tubuh dari virus. Virus Covid-19 kini sudah memasuki wilayah Indonesia. Agar tidak tertular, menjaga daya tahan tubuh jadi salah satu langkah pencegahan virus Covid-19 [2]. Kebutuhan masyarakat terhadap produk Vitamin-C belakangan ini sangat besar, dikarenakan banyaknya kegiatan yang dilakukan masyarakat sehingga perlu adanya Vitamin-C sebagai antioksidan dan menjaga kekebalan tubuh terhadap berbagai penyakit. Vitamin-C sangat diperlukan tubuh manusia setiap harinya, sebagai bentuk Vitamin-C yang mudah diminum biasanya dalam bentuk tablet, kapsul atau cairan. Banyaknya bentuk dan pilihan merk Vitamin-C membuat masyarakat sering bingung memilih produk Vitamin-C mana untuk dikonsumsi di masa pandemi Covid-19 ini. Untuk itu perlu adanya suatu pengambilan keputusan untuk memilih produk Vitamin-C dengan Sistem Pendukung Keputusan Menggunakan Metode Weighted Products (WP) dapat membantu dalam mengambil keputusan pemilihan Vitamin-C di masa pandemi Covid-19 dengan cara yang cepat, efisien dan efektif. Metode Weighted Product (WP) merupakan salah satu metode yang digunakan untuk menyelesaikan masalah Multi Attibute Decision Making (MADM). MADM adalah menentukan nilai bobot untuk setiap atribut, kemudian dilanjutkan dengan proses perangkingan yang akan menyeleksi alternatif yang sudah diberikan [3].

Penelitian yang pernah dilakukan menggunakan Metode Weighted Product (WP) diantaranya penelitian mengenai sistem pemilihan laptop terbaik untuk membantu rekomendasi dalam pemilihan laptop terbaik di Sekolah SMK Mandiri Bekasi dengan menggunakan lima kriteria diantaranya prosesor, RAM, harddisk, VGA dan harga [4]. Pemilihan teknisi komputer terbaik sesuai dengan kompetensi yang dimilikidengan menggunakan lima kriteria diantaranya pemahaman komputer, pemahaman jaringan, pendidikan, disiplin dan kepribadian [5]. Kriteria di tentukan untuk menjadi acuan dalam pengambilan keputusan di metode weight produk dengan menggunakan empat kriteria yaitu harga, print warna, print hitam dan berat untuk keputusan pemilihan printer terbaik [6]. Kelebihan Metode Weighted Product (WP) ini terdapat variabel cost dan benefit yang berguna untuk menentukan kriteria yang berpengaruh terhadap keputusan [6]. Sedangkan kekurangan pada metode Weighted Product (WP) ini hanya untuk digunakan pada proses nilai yang memiliki nilai rentang [4].

\section{METODE PENELITIAN}

\subsection{Tahapan Penelitian}

Gambar 1 merupakan tahapan penelitian yang dilakukan untuk mencapai tujuan yang telah ditetapkan sebelumnya.
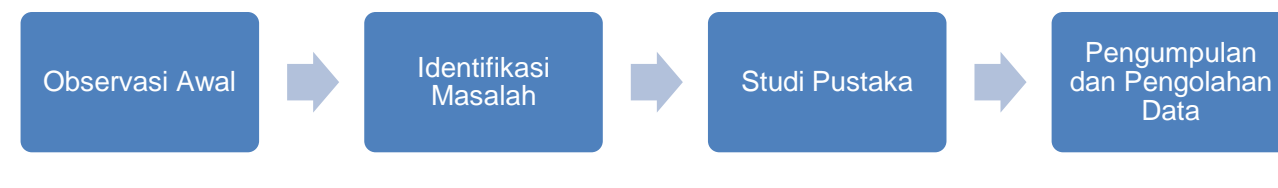

Gambar 1. Tahapan Penelitian 
Masing-masing tahapan penelitian diuraikan secara rinci sebagai berikut :

1. Observasi Awal

Tahap awal melakukan observasi atau pengamatan secara langsung pada Toko Obat terdekat untuk mendapatkan informasi yang dibutuhkan seputar merk, bentuk, harga dan komposisi pada Vitamin-C untuk membantu dalam menyelesaikan penyusunan penelitian.

2. Identifikasi Masalah

Pada tahap ini dilakukan identifikasi masalah yang terjadi berdasarkan latar belakang masalah yang telah ditentukan. Masalah yang ditemukan adalah banyaknya konsumen yang mengkonsumsi vitamin $\mathrm{c}$ sulit dalam memilih atau menentukan vitamin c mana yang akan dikonsumsinya. Sedangkan tujuan dari penelitian ini adalah sistem yang dihasilkan dapat membantu konsumen dalam memilih dan menentukan vitamin c mana yang akan dikonsumsinya.

3. Studi Pustaka

Pada tahap ini dilakukan dengan mencari referensi penelitian terlebih dahulu yang berkaitan dengan tema dan tujuan penelitian serta mempelajari buku, jurnal, bahan pustaka yang ada di internet untuk mendapatkan informasi mengenai masalah yang dibahas pada penelitian ini.

4. Pengumpulan dan Pengolahan Data

Pada tahap ini dilakukan dengan menyebar kuesioner kepada responden secara online sebagai teknik pengumpulan data. Setelah data terkumpul, dilakukan pengolahan data yang digunakan pada tahap analisis data dengan menerapkan metode Weighted Product (WP).

5. Kesimpulan dan Saran

Pada tahap ini merupakan tahapan akhir dari proses penelitian dengan menyimpulkan hasil yang telah dilakukan terhadap penelitian dan merumuskan saran yang berkaitan dengan penelitian ini.

\subsection{Populasi dan Sampel Penelitian}

Rumus slovin digunakan dalam menentukan jumlah sampel yang dibutuhkan dari sebuah populasi, Rumus Slovin adalah rumus yang digunakan untuk menghitung jumlah sampel minimum untuk suatu penelitian yang memperkirakan suatu perbandingan [7].

$$
n=\frac{N}{1+N(e)^{2}}
$$

Keterangan :

$\mathrm{n}=$ Jumlah sampel

$\mathrm{N}=$ Total populasi

$\mathrm{e}=$ Tingkat kesalahan dalam pengambilan sampel

$$
n=\frac{100}{1+100(10 \%)^{2}}=\frac{100}{2}=50
$$

Menggunakan tingkat kesalahan $10 \%$ dari 100 responden, maka dihasilkan responden dalam penelitian ini sebanyak 50 responden.

\subsection{Analisis Data}

Dalam penelitian ini kuesioner sebagai pengumpulan data yang dilakukan dengan memberi pertanyaan mengenai objek yang sedang diteliti kepada responden secara online melalui google form. Penelitian ini menggunakan metode skala likert yang terdiri 5 poin jawaban pada setiap pertanyaan yang diajukan. Pilihan dari sangat tidak setuju hingga sangat setuju dengan masing-masing jawaban memiliki nilai, berikut pada tabel 1 dibawah ini :

Tabel 1. Pemberian Nilai Jawaban Kuesioner

\begin{tabular}{cccc}
\hline No. & Jawaban & Kode & Nilai \\
\hline 1 & Sangat Setuju & SS & 5 \\
2 & Setuju & S & 4 \\
3 & Ragu Ragu & R & 3 \\
4 & Tidak Setuju & TS & 2 \\
5 & Sangat Tidak Setuju & STS & 1 \\
\hline
\end{tabular}

Untuk menentukan pemilihan vitamin c di masa pandemi covid-19 dengan metode Weighted Product (WP), diperlukan kriteria yaitu harga, keterangan, merk dan komposisi. Kriteria tersebut dipilih karena memiliki pengaruh yang cukup besar untuk menentukan pemilihan vitamin c di masa covid-19 sekarang ini. Kriteria yang telah dipilih dapat dilihat pada tabel 2 di bawah ini. Tabel 3 merupakan nilai bobot kriteria dan tabel 4 merupakan skala penilaian yang berlaku. 
Tabel 2. Kriteria

\begin{tabular}{cc}
\hline Keterangan & Kriteria \\
\hline Harga & $\mathrm{C} 1$ \\
Bentuk & $\mathrm{C} 2$ \\
Merk & $\mathrm{C} 3$ \\
Komposisi & $\mathrm{C} 4$ \\
\hline
\end{tabular}

Tabel 3. Nilai Bobot Kriteria

\begin{tabular}{cccc}
\hline Kriteria & Bobot & Cost/Benefit & Kode \\
\hline Harga & 5 & Cost & $\mathrm{C} 1$ \\
Bentuk & 3 & Benefit & $\mathrm{C} 2$ \\
Merek & 4 & Benefit & $\mathrm{C} 3$ \\
Komposisi & 4 & Benefit & $\mathrm{C} 4$ \\
\hline Jumlah & $\mathbf{1 6}$ & & \\
\hline
\end{tabular}

Tabel 4. Skala Penilaian

\begin{tabular}{cc}
\hline Bobot Kepentingan & Predikat \\
\hline 1 & Tidak Penting \\
2 & Kurang Penting \\
3 & Cukup Penting \\
4 & Penting \\
5 & Sangat Penting \\
\hline
\end{tabular}

Tabel 5 merupakan sampel data yang digunakan dalam penelitian ini. Alternatif yang digunakan dalam pengolahan data ini menggunakan 50 alternatif yaitu dimulai dengan A1 sampai dengan A50.

Tabel 5. Sampel Data Penelitian

\begin{tabular}{|c|c|c|c|c|}
\hline Alternatif & C1 & C2 & C3 & C4 \\
\hline A1 & 5 & 5 & 4 & 4 \\
\hline A2 & 5 & 5 & 3 & 4 \\
\hline A3 & 5 & 2 & 5 & 5 \\
\hline A4 & 5 & 5 & 5 & 5 \\
\hline A5 & 5 & 4 & 5 & 4 \\
\hline A6 & 4 & 4 & 4 & 4 \\
\hline A7 & 4 & 4 & 4 & 4 \\
\hline A8 & 5 & 4 & 4 & 5 \\
\hline A9 & 4 & 4 & 5 & 5 \\
\hline A10 & 4 & 4 & 4 & 3 \\
\hline A11 & 4 & 3 & 5 & 4 \\
\hline A12 & 4 & 5 & 4 & 4 \\
\hline A13 & 4 & 5 & 4 & 4 \\
\hline A14 & 4 & 4 & 4 & 5 \\
\hline A15 & 3 & 5 & 5 & 3 \\
\hline A16 & 4 & 4 & 4 & 4 \\
\hline A17 & 3 & 3 & 3 & 3 \\
\hline A18 & 3 & 5 & 4 & 2 \\
\hline A19 & 5 & 5 & 5 & 5 \\
\hline A20 & 5 & 5 & 5 & 5 \\
\hline & & & & \\
\hline
\end{tabular}




\begin{tabular}{|c|c|c|c|c|}
\hline Alternatif & C1 & $\mathrm{C2}$ & C3 & C4 \\
\hline $\mathrm{A} 21$ & 3 & 4 & 3 & 3 \\
\hline $\mathrm{A} 22$ & 5 & 5 & 4 & 4 \\
\hline A23 & 5 & 5 & 5 & 5 \\
\hline A 24 & 3 & 1 & 2 & 2 \\
\hline A25 & 4 & 4 & 3 & 4 \\
\hline A26 & 4 & 5 & 5 & 4 \\
\hline A27 & 5 & 5 & 5 & 5 \\
\hline A 28 & 5 & 4 & 4 & 4 \\
\hline A29 & 5 & 4 & 4 & 4 \\
\hline A 30 & 5 & 5 & 4 & 4 \\
\hline A 31 & 4 & 4 & 4 & 4 \\
\hline A 32 & 4 & 4 & 4 & 4 \\
\hline A33 & 4 & 5 & 5 & 5 \\
\hline A34 & 4 & 4 & 4 & 4 \\
\hline A 35 & 4 & 4 & 4 & 4 \\
\hline A 36 & 3 & 3 & 3 & 3 \\
\hline A 37 & 5 & 5 & 4 & 5 \\
\hline A38 & 4 & 4 & 4 & 4 \\
\hline A39 & 3 & 5 & 5 & 5 \\
\hline A 40 & 4 & 4 & 4 & 4 \\
\hline A41 & 5 & 5 & 4 & 4 \\
\hline $\mathrm{A} 42$ & 5 & 5 & 5 & 5 \\
\hline A43 & 4 & 5 & 4 & 4 \\
\hline A44 & 5 & 5 & 4 & 4 \\
\hline A45 & 4 & 5 & 4 & 4 \\
\hline A46 & 5 & 5 & 5 & 4 \\
\hline A 47 & 4 & 4 & 4 & 4 \\
\hline $\mathrm{A} 48$ & 4 & 5 & 4 & 5 \\
\hline A49 & 5 & 5 & 5 & 5 \\
\hline A50 & 5 & 5 & 5 & 4 \\
\hline
\end{tabular}

\section{HASIL DAN ANALISIS}

\subsection{Perhitungan Metode Weighted Product (WP)}

Berdasarkan alternatif, kriteria dan bobot yang telah ditentukan maka tahap selanjutnya adalah perhitungan mengggunakan metode Weighted Product (WP).

1. Melakukan Perbaikan Bobot

Untuk melanjutkan perhitungan menggunakan metode Weighted Product (WP), terlebih dahulu dilakukan perbaikan bobot untuk setiap kriteria yang digunakan. Berdasarkan perhitungan sesuai rumus yang digunakan maka perbaikan bobot adalah $\sum \mathrm{W}_{\mathrm{j}}=1$. Tabel 6 merupakan hasil dari perhitungan perbaikan bobot.

$$
\begin{aligned}
& W_{j}=\frac{W_{j}}{\sum_{j=1}^{n} W_{j}} \\
& W_{1}=\frac{5}{5+3+4+4}=\frac{5}{16}=0,31 \\
& W_{2}=\frac{3}{5+3+4+4}=\frac{3}{16}=0,19
\end{aligned}
$$




$$
\begin{aligned}
& W_{3}=\frac{4}{5+3+4+4}=\frac{4}{16}=0,25 \\
& W_{4}=\frac{4}{5+3+4+4}=\frac{4}{16}=0,25
\end{aligned}
$$

Tabel 6. Hasil Perhitungan Perbaikan Bobot

\begin{tabular}{ccc}
\hline Kriteria & Keterangan & Nilai \\
\hline C1 & Harga & 0.31 \\
C2 & Bentuk & 0.19 \\
C3 & Merk & 0.25 \\
C4 & Komposisi & 0.25 \\
\hline$\sum \boldsymbol{w}_{\boldsymbol{j}}$ & & $\mathbf{1}$ \\
\hline
\end{tabular}

2. Perhitungan Normalisasi Vektor $\mathrm{S}$

Setelah melakukan perhitungan perbaikan bobot, langkah selanjutnya adalah perhitungan untuk menentukan normalisasi vektor s. tabel 7 merupakan hasil perhitungan normalisasi vektor s sesuai dengan rumus yang digunakan.

$$
\prod_{j=1}^{n} X_{i j}{ }^{w j}
$$

$$
\begin{aligned}
& S^{1}=\left(5^{-0,31}\right)\left(5^{0,19}\right)\left(4^{0,25}\right)\left(4^{0,25}\right)=1,636 \\
& S_{2}=\left(5^{-0,31}\right)\left(5^{0,19}\right)\left(3^{0,25}\right)\left(4^{0,25}\right)=1,522 \\
& S_{3}=\left(5^{-0,31}\right)\left(2^{0,19}\right)\left(5^{0,25}\right)\left(5^{0,25}\right)=1,540 \\
& S_{4}=\left(5^{-0,31}\right)\left(5^{0,19}\right)\left(5^{0,25}\right)\left(5^{0,25}\right)=1,829 \\
& S_{5}=\left(5^{-0,31}\right)\left(4^{0,19}\right)\left(5^{0,25}\right)\left(4^{0,25}\right)=1,659 \\
& S_{6}=\left(4^{-0,31}\right)\left(4^{0,19}\right)\left(4^{0,25}\right)\left(4^{0,25}\right)=1,682 \\
& S_{7}=\left(4^{-0,31}\right)\left(4^{0,19}\right)\left(4^{0,25}\right)\left(4^{0,25}\right)=1,682 \\
& S_{8}=\left(5^{-0,31}\right)\left(4^{0,19}\right)\left(4^{0,25}\right)\left(5^{0,25}\right)=1,659 \\
& S_{9}=\left(4^{-0,31}\right)\left(4^{0,19}\right)\left(5^{0,25}\right)\left(5^{0,25}\right)=1,880 \\
& S_{10}=\left(4^{-0,31}\right)\left(4^{0,19}\right)\left(4^{0,25}\right)\left(3^{0,25}\right)=1,565
\end{aligned}
$$

Tabel 7. Hasil Perhitungan Normalisasi Vektor S

\begin{tabular}{cc} 
Alternatif & Vektor S \\
\hline A1 & 1.636 \\
A2 & 1.522 \\
A3 & 1.540 \\
A4 & 1.829 \\
A5 & 1.659 \\
A6 & 1.682 \\
A7 & 1.682 \\
A8 & 1.659 \\
A9 & 1.880 \\
A10 & 1.565 \\
s.d A50 & 1.729 \\
\hline
\end{tabular}

3. Perhitungan Nilai Preferensi Vektor V

Setelah melakukan perhitungan Normalisasi Vektor S selanjutnya adalah perhitungan nilai preferensi vektor v. Langkah ini dilakukan untuk mendapatkan hasil akhir dari perhitungan menggunakan metode Weighted Product (WP).

$$
V_{\mathrm{i}}=\frac{S_{i}}{S_{1}+S_{2}+S_{3} \ldots S_{n}}
$$




$$
\begin{aligned}
& V_{1}=\frac{1,636}{84,920}=0,0193 \\
& V^{2}=\frac{1,522}{84,920}=0,0179 \\
& V_{3}=\frac{1,540}{84,920}=0,0181 \\
& V_{4}=\frac{1,829}{84,920}=0,0215 \\
& V_{5}=\frac{1,659}{84,920}=0,0195 \\
& V_{6}=\frac{1,682}{84,920}=0,0198 \\
& V_{7}=\frac{1,682}{84,920}=0,0198 \\
& V_{8}=\frac{1,659}{84,920}=0,0195 \\
& V_{8}=\frac{1,659}{84,920}=0,0195 \\
& V_{10}=\frac{1,565}{84,920}=0,0184
\end{aligned}
$$

Tabel 8. Hasil Perhitungan Nilai Preferensi Vektor V

\begin{tabular}{cc}
\hline Alternatif & $\mathrm{V}$ \\
\hline A1 & 0.0193 \\
A2 & 0.0179 \\
A3 & 0.0181 \\
A4 & 0.0215 \\
A5 & 0.0195 \\
A6 & 0.0198 \\
A7 & 0.0198 \\
A8 & 0.0195 \\
A9 & 0.0221 \\
A10 & 0.0184 \\
s.d A50 & 0.0204 \\
\hline
\end{tabular}

4. Penentuan Ranking

Setelah perhitungan selesai dilakukan, maka langkah berikutnya adalah mengurutkan atau melakukan perangkingan hasil perhitungan nilai tertinggi sampai dengan nilai terendah. Tabel 9 menunjukan lima nilai teratas dari hasil perangkingan terhadap perhitungan yang sudah dilakukan.

Tabel 9. Hasil Perankingan

\begin{tabular}{cccc}
\hline Alternatif & Hasil & Merk Vitamin-C & Rangking \\
\hline A39 & 0,0253 & You C 1000 & 1 \\
A33 & 0,0231 & Vitacimin & 2 \\
A15 & 0,0222 & Vitalog C & 3 \\
A9 & 0,0221 & Redoxon Double Action & 4 \\
A26 & 0,0218 & Enervon C & 5 \\
\hline
\end{tabular}

Pada tabel 7 diatas, maka dapat dilihat dari hasil Vektor $\mathrm{V}$ yang tertinggi dalam pemilihan vitamin-c di masa pandemi Covid-19 yang menjadi peringkat 1 merk Vitamin-C You C 1000 dengan hasil 0,0253, peringkat 2 merk Vitamin-C Vitacimin dengan hasil 0,0231, peringkat 3 merk Vitamin-C Vitalog $\mathrm{C}$ dengan hasil 0,0222, peringkat 4 merk Vitamin-C Redoxon Double Action dengan hasil 0,0221 dan peringkat 5 merk Vitamin-C Enervon C dengan hasil 0,0218. 


\section{KESIMPULAN}

Berdasarkan hasil perhitungan yang telah dilakukan, dapat disimpulkan bahwa menggunakan metode Weighted Product (WP) dengan beberapa kriteria yaitu harga, bentuk, merk dan kompisisi dapat membantu pengambilan keputusan dalam memilih produk vitamin-c untuk dikonsumsi pada masa pandemi Covid-19. Dari hasil perhitungan yang telah diperoleh bahwa merk vitamin-c You C 1000 mendapatkan nilai tertinggi yaitu 0,0253 yang dapat direkomendasikan sebagai pilihan utama bagi masyarakat dalam memilih produk vitamin-c untuk dikonsumsi di masa pandemi Covid-19, karena You C 1000 suplemen vitamin berbentuk cair yang mudah diminum, juga terdapat kandungan Vitamin-C 1000 miligram yang dapat dikonsumsi setiap hari untuk meningkatkan imun tubuh serta melawan radikal bebas dari virus.

\section{UCAPAN TERIMA KASIH}

Terima kasih kami ucapkan kepada pihak-pihak yang telah membantu sehingga penelitian ini dapat selesai dilaksanakan.

\section{REFERENSI}

[1] M. Covid-, Y. E. Nopiyanto, S. Raibowo, and T. Sugihartono, "Pola Hidup Sehat Dengan Olahraga dan Asupan Gizi Untuk Meningkatkan Imun Tubuh,” Jurnal Ilmiah Pengembangan dan Penerapan IPTEKS, vol. 18, no. 02, pp. 90-100, 2020.

[2] “Tingkatkan Daya Tahan Tubuh Cegah Virus Dengan Vitamin C," 2020.

[3] Y. Zai, Mesran, and E. Buulolo, "Sistem Pendukung Keputusan untuk Menentukan Buah Rambutan Dengan Kualitas Terbaik Menggunakan Metode Weighted Product (WP)," Media Informatika Budidarma (MIB), vol. 1, no. 1, pp. 8-11, 2017.

[4] R. R. Aria and S. Susilowati, "SISTEM PEMILIHAN LAPTOP TERBAIK DENGAN MENGGUNAKAN METODE WEIGHTED PRODUCT ( WP ),” vol. 16, no. 1, pp. 15-20, 2019.

[5] P. N. Medan and J. Almamater, "SISTEM PENDUKUNG KEPUTUSAN PEMILIHAN TEKNISI KOMPUTER TERBAIK DENGAN MENGGUNAKAN METODE WEIGHTED PRODUCT," Jurnal Teknik Ibnu Sina, vol. 4, no. 2, pp. 33-38, 2019.

[6] H. Nurinadi and Y. Brianorman, "PERBANDINGAN DALAM PEMILIHAN PRINTER MENGGUNAKAN," no. November, pp. 38-43, 2020.

[7] W. A. Wirawan, A. Aghastya, and A. L. Lailya, "Permodelan Alat Penghitung Jumlah Penumpang Kereta Berbasis Mikrokontroler Atmega 2560," Jurnal Perkeretaapian Indonesia, vol. 3, no. 1, pp. 5561, 2019. 